INTERNATIONAL JOURNAL OF RESEARCHES IN BIOSCIENCES, AGRICULTURE AND TECHNOLOGY

(C) VISHWASHANTI MULTIPURPOSE SOCIETY (Global Peace Multipurpose Society) R. No. MH-659/13(N)

www.vmsindia.org

\title{
THE INFLUENCE OF SOME BOTANICALS AGAINST RICE WEEVIL DURING STORAGE IN RABI SORGHUM
}

\author{
Rajesh Gadewar ${ }^{1}$, Vipin Babhulkar ${ }^{2}$, Prachi Lambat ${ }^{3}$, \\ Ashish Lambat ${ }^{4}$, Ramesh Parate ${ }^{5}$ and Sanjiv Charjan ${ }^{6}$ \\ 1,4 Sevadal Mahila Mahavidyalaya and Research Academy, Nagpur (MS) \\ 2,5,6 Dr. PDKV's College of Agriculture, Nagpur. \\ 3 Shri Mathuradas Mohata Science College, Nagpur
}

\begin{abstract}
: control during storage.

\section{Introduction:}

The Rice Weevil (Sitophilus Oryzea) is a serious pest of stored grain causing considerable damage to almost all cereals in storage. It is largely responsible for damage and frequently harboring store, mill and warehouses. Rice Weevil is cosmopolitan in nature attributing about $50 \%$ loss in seed weight during storage.

The steady rise in the use of pesticides for control of store grain pests can be dangerous to human being and cattle as well due to their residual toxicity. With view to find out safe and organic seed protectants, present investigation was taken up to evaluate the organic grain protectants in seed storage against Rice Weevil in Rabi Sorghum .
\end{abstract}

The Rice Weevil (Sitophilus Oryzea) is a serious store grain pest of wheat during storage. In the present investigation, the experiment was conducted to know the effect of different organic grain protectants on infestation percentage of Rice Weevil and seed qualities of Rabi Sorghum CV.Maldandi. It was observed that seed treated with sweet flag powder $(2.5 \%)$ and custard apple seed powder $2.5 \%$ were showed significantly higher 100 seed weight, germination percentage, seedling vigour, field emergence percentage and adult mortality as compared to other seed treatment and

Key words :- organic grain protectants, sweet flag, custard apple, Rice Weevil, Rabi Sorghum.

\section{Material and Methods:}

Rabi Sorghum CV. Maldandi seed were used in various phages of this study, produced in 2014-2015. The seed were cleaned and dried (moisture content 10.5\%). The wheat seed were treated (May 2014) with six plant product viz., Neem leaf, sweet flag, Tulsi, Custard apple, Turmeric and Pongamia powder is in the proportion of $2.5 \%$ by weight of the seeds. The experiment as conducted in glass bottle of 1 lit capacity with seven treatments including untreated control. Each glass bottle was then filled with $500 \mathrm{gm}$ of Rabi Sorghum seeds. 10 pairs of 2-3 days old Rice Weevil were released in each glass bottle covered with muslin cloth. The set of experiment was kept in well ventilated wire mesh almirah in masonry building having cemented walls, roof and floor under ambient temperature $\left(23.2-45.6^{\circ} \mathrm{C}\right)$ and relative humidity (21-85\%) from May to July, 2014. After three months the seed from each treatment were keenly observed and those found infested were separated out weighted to determine the infestation percentage on weight basis hundred seed weight and germination were tested in quadruplicate with 100 seed in each replication. The germination percentage was evaluated on the value for normal seedling (Anon. 1985). The vigour index were workout following the method of Abdul Baki and Anderson (1973). For field emergence test, sowing of wheat seed was done in randomized block design, with four replication with inter and intra row spacing of one feet and six inches respectively. Observations for field emergence were recorded daily and finally the established seedlings were counted after one month of sowing. The experimental data was statistically scrutinized as per the Panse and Sukhatme (1967).

\section{Result and Discussion:}

The data regarding the effect of the different organic grain protectants on population behavior (Adult mortality) infestation percentage 100 seed weigh, germination percentage, vigour index and field emergence percentage after three months of storage are given in table 1 .

The result indicated that variation in number of Rice Weevil (adult) in each treatment. The Rice Weevil adult mortality was significantly highest in Rabi Sorghum seed treated with sweet flag $(97 \%)$ which is closely followed by custard apple $(86 \%)$ neem leaf $(66 \%)$, pongamia $(65 \%)$, tulsi $(60 \%)$ and turmeric (59\%). Where in significantly lower mortality was observed in untreated control (7\%). Saxenaet. Al (1976), Tikku et al. (1978) and Khan and Borle (1985) found Acorus calamus L oil vapour responsible for 
causing infecundity among the female of a number stored grain pest. Biradar (2000) who reported that sweet flag has got insecticidal and ovicidal effect. The significantly maize seed weight loss was observed in untreated control followed by turmeric, tulsi, pongmia, neem leaf, custard apple and sweet flag treatment during entire period of storage. This might be due to sterilizing effect of sweet flag rhizome powder mixed with maize seeds. Charjan and Tarar (1994), Deshpande et al. (2010), Ashish et al. (2011), and K. Cherian et al. (2011) reported that the sharp declined in infestation percentage of store grain pest in seed treated with Acorus calamus powder.

The seed quality parameters viz., 100 seed weight, germination percentage and seedling vigour index was highest in seed treated with $2.5 \%$ concentration of sweet flag powder followed by custard apple, neem leaf, pongamia, tulsi, turmeric and untreated control. The 100 seed weight, germination percentage and vigour index decreased with increasing infestation fo stored grain pest Howe, (1972), Charjan and Tarar (1994), Deshpande et al. (2010) and Ashish Lambat et al (2011). Since the stored grain pest have been eaten off major portion of the endosperm which leads to reduction in weight of the maize seeds and in turn affect the seed germination and vigour index because of lack of stored food and is in conformity with the findings of Narayanswami (1985). Handerson ad
Christensen (1961) reported that pulse beetle attack the embryo and germination potential of seed reduced or totally destroyed.

The field emergence percentage of Rabi Sorghum seeds follow the same trends of seed quality parameters. The field emergence percentage was highest in seed treated with $2.5 \%$ concentration of sweet flag powder as compared to other treatments and untreated control. This might be due to the least infestation of Rice Weevil and higher 100 seed weight, germinability and seedling vigour index. The results are agreement to those reported by Charjan and Tarar (1994), Deshpande et al. (2010), Ashish Lambat et al (2010) and K. Cherian et al (2011).

Among the plant products sweet flag powder $2.5 \%$ were found to be significantly effective against Rice Weevil throughout the period of investigation these findings are agreement with Siva Srinivasu (2001), Deshpande et al. (2010), Charjan and Tarar (1994) and Ashish Lambat et al (2011) thus sweet flag and custard apple naturally occurring botanicals which are not toxic can be used as pre storage seed treatment, dispensing with the use of costly and toxic can be used as pre storage seed treatment, dispensing with the use of costly and toxic chemicals to control Rice Weevil damage without adversely affecting the germination of Rabi Sorghum seed.

Table No. 1: The Effect of different organic protectants on Rice Weevilmortality, infestation percentage, 100 seed weight, germination percentage, seedling vigour and field emergence percentage.

\begin{tabular}{|l|c|c|c|c|c|c|}
\hline Treatments & $\begin{array}{l}\text { Adult } \\
\text { Mortality } \\
(\%)\end{array}$ & $\begin{array}{l}\text { Prevent weight } \\
\text { loss due to } \\
\text { infestation (\%) }\end{array}$ & $\begin{array}{l}100 \\
\text { seed } \\
\text { weight }\end{array}$ & $\begin{array}{l}\text { Germination } \\
(\%)\end{array}$ & SVI & $\begin{array}{l}\text { Field } \\
\text { Emergence } \\
(\%)\end{array}$ \\
\hline Neem Leaf (2.5\%) & 66 & 5.8 & 2.1 & 76 & 1360 & 65 \\
\hline Sweet flag (2.5\%) & 97 & 0.4 & 2.3 & 99 & 2030 & 90 \\
\hline Tulsi (2.5\%) & 60 & 7.01 & 2.0 & 74 & 1318 & 64 \\
\hline Custard apple (2.5\%) & 86 & 3.0 & 2.3 & 94 & 2010 & 85 \\
\hline Turmeric (2.5\%) & 59 & 7.1 & 1.7 & 70 & 1150 & 60 \\
\hline Pongamia (2.5\%) & 65 & 7.17 & 2.1 & 73 & 1230 & 63 \\
\hline Untreated control & 7 & 18.00 & 1.9 & 36 & 660 & 21 \\
\hline SEm ( + ) & 0.30 & 0.10 & 0.03 & 0.10 & - & 0.11 \\
\hline CD at 5\% & 0.91 & 0.30 & 0.09 & 0.30 & - & 0.33 \\
\hline
\end{tabular}

\section{References:}

Abdul Baki, A.A. and Anderson J.D. 1973 Vigour determination in soybean seed by multiple criteria. Crop sci. 13: 630-633.

Anonymous, 1985 International rules for seed testing. Seed Sci. and Technol. 13: 299-513

Ashish Lambat, Rajesh Gadewar, Sanjeev Charjan, Konglath Cherian and Prachi Lambat, 2011. Evaluation of organic grain protectants in seed storage against rice weevil in wheat. Proc. Of International conference on Sustainable Environment held during 19-20 February 2011 at Aurangabad, Maharashtra, India. Special issue $6: 122-123$.
Biradar, B.S. 2000 Prevention of cross infestation by Sitophilus oryzae L. and Rhizopertha dominica in stored wheat. M.Sc. (Agri.) Thesis, University of Agricultural Sciences, Dharwd.

Charjan S.K.U. and Tarar, J.L. 1994 The influence of some plant products on seed quality of lobia during storage. Ann. Plant Physiol. 8 (2) L : 153-156

Deshpande, V.K. Deshpande, H.H. and Masuthi, D. 2010 Evaluation of grain protectants in seed storage against Sitophilus oryzae (L.) in sorghum. Green farming 1(5):512-514. 
Harderson, L.S. and Christensen, C.M. 1961 Preharvest control of insect and fungi. U.S. Dept. Agri. Ybk, pp. 348-356.

Howe, R.W. 1972 Insect attacking seed during storage.Seed Biology vol. III (ed. Kozlowski, T.T.) Academic press: New York pp. 247-300.

Khan, M.I. and Borle, M.N. 1985 Efficacy of some safer grain protectants against the pulse beetle, Collosobruchuschenensis L. infecting stored Bengal gram (Cicerarietinum L. ) P.K.V. Res. J 9(1) : 53-55.

Narayanaswamy, S 1985 Effect of Pulse beetle damage on seed quality of field bean and Pigeon pea. Seed Res. 13 (2) : 138-141.

wheat.Proc. Of National Seminar on Environmental Management and Biodiversity conservation, held during 26-27 February 2011 at Rishikesh (U.K.) India. Abstract no. A127 page 101.

KonglathCherian, SanjeevCharjan, Vandan Mohod,

Ashish Lambat and Rajesh Gadewar 2011. Studies on the influence of Acorus clamus L. rrhizome Powder seed treatments against stored grain pest of

Panse, V.G. and Sukhatme, P.V. 1967. Statistical methods for agricultural workers. I.C.A.R. Pub., New Delhi.

Saxena, B.P., Koul, O. and Tikku, K. 1976. Non toxic protectants against the stored grain insect pest. Bull. Grain Technol. 14(5): 1990-193.

Tikku K., Koul, O. and Saxena B.P. 1978. The influence of Acoruscalamus L. oil vapour on the histocytological pattern of the ovaries of Trogoderma granarium Evert. Bull. Grain Tehnol. 